\title{
PENGARUH EKSTRAK ETANOL DAUN GAMBIR (UNCARIA GAMBIR) DIBANDINGKAN DENGAN CHLORHEXIDINE GLUCONATE 0,2\% TOPIKAL TERHADAP PENYEMBUHAN LUKA MUKOSA PALATUM TIKUS GALUR WISTAR
}

\author{
(EFFECT OF ETHANOL GAMBIR LEAVES (UNCARIA GAMBIR) COMPARED WITH \\ CHLORHEXIDINE GLUCONATE 0,2\% TOPICAL FOR WOUND HEALING ON \\ PALATE MUCOSAL GALUR WISTAR RAT)
}

\author{
Dita Septiani, Euis Reni Yuslianti, Saskia Lenggogeni Nasroen \\ Departemen Oral Biologi \\ Fakultas Kedokteran, Universitas Jenderal Achmad Yani \\ Jl. Terusan Jenderal Sudirman Cimahi
}

\begin{abstract}
Gambir (Uncaria gambir) used empirically in helping wound healing because it has the ability as an antibacterial, antiinflammatory and antioxidant. This study was to determine the effect of ethanol extract of gambir leaves on wound healing rat palatal mucosal wistar strain and determine the effective dose of ethanol extract of gambir leaves topically for optimal wound healing. Research method used pure experimental research design with analytic laboratory design. Object of research were wistar strain rats, and randomly divided into seven groups: negative control, positive control group by using chlorexidine gluconate $0.2 \%$, and the group of ethanol gambir leaves extract at a dose of $1.75 \mathrm{mg}, 3.5 \mathrm{mg}, 7 \mathrm{mg}, 14$ $\mathrm{mg}$ and $28 \mathrm{mg}$ in the semisolid dosage forms. Wounds were observed on days $0,3,7$ and 14 . The results showed that the ethanol extract of gambir leaves have effect on wound healing, it is related to the content of gambir leaves such as catechins, cathechutannat acids, quersetins, tannins, alkaloids, saponins and gambiriins which acts as an antibacterial, antiinflammatory and antioxidant. The results of statistical tests wound surface area with the Kruskal-Wallis test showed the value of $p=0,00$ and statistical test results with the dose effectiveness Friedman test showed the value of $p=0,00$. In conclusion, the ethanol extract of gambir leaves can be more quickly to reduce wider and longer than chlorhexidine gluconate $0.2 \%$ wound healing and gained effective dose was $28 \mathrm{mg}$.
\end{abstract}

Key words: Gambir leaf, effective dose, wound

\begin{abstract}
Abstrak
Gambir (Uncaria gambir) digunakan masyarakat secara empiris dalam membantu penyembuhan luka karena memiliki kemampuan antibakteri, antiinflamasi dan antioksidan. Penelitian ini bertujuan mengetahui pengaruh ekstrak etanol daun gambir topikal terhadap penyembuhan luka mukosa palatum tikus galur wistar dibandingkan chlorhexidine gluconate $0,2 \%$ ditinjau dari luas permukaan luka dan lama penyembuhan luka serta mengetahui dosis efektif ekstrak etanol daun gambir secara topikal untuk penyembuhan luka optimal. Metode penelitian menggunakan rancangan penelitian eksperimental murni laboratoris bersifat analitik. Tikus dibagi acak menjadi tujuh kelompok yaitu kelompok kontrol negatif, kelompok chlorexidine gluconate 0,2\%, kelompok ekstrak etanol daun gambir dosis 1,75 mg, 3,5 mg, $7 \mathrm{mg}, 14$ $\mathrm{mg}$ dan $28 \mathrm{mg}$. Luka diamati hari ke-0, 3, 7 dan 14. Hasil penelitian menunjukkan ekstrak etanol daun gambir berpengaruh terhadap penyembuhan luka berhubungan dengan kandungan daun gambir yaitu katekin, asam cathechutannat, quersetin, tanin, alkaloid, saponin dan gambiriin berperan sebagai antibakteri, antiinflamasi dan antioksidan. Hasil tes statistik luas permukaan luka dengan uji Kruskal-Wallis menunjukkan nilai $\mathrm{p}=0,00$ dan hasil tes statistik efektivitas dosis dengan uji Friedman menunjukkan nilai $\mathrm{p}=0,00$. Sebagai kesimpulan, ekstrak etanol daun gambir dapat lebih cepat memperkecil luas dan lama penyembuhan luka dibandingkan chlorhexidine gluconate $0,2 \%$ serta didapatkan dosis efektif yaitu $28 \mathrm{mg}$.
\end{abstract}

Kata kunci: Daun gambir, dosis efektif, luka 


\section{PENDAHULUAN}

Luka merupakan kehancuran atau lenyapnya komponen jaringan tubuh yang disebabkan cedera benda tumpul atau runcing, digigit binatang, ataupun tersengat listrik. Proses tubuh untuk melakukan penyembuhan luka terdiri atas tiga tahapan yaitu fase inflamasi, fase proliferasi dan dilanjutkan fase remodeling. Proses penyembuhan luka dapat terhambat karena faktor yang berasal dari dalam tubuh (endogen) ataupun dari luar tubuh (eksogen). ${ }^{1}$

Bahan alami yang banyak digunakan sebagian masyarakat untuk penyembuhan luka salah satunya adalah gambir. Gambir dengan nama ilmiah $U n-$ caria gambir adalah tanaman yang secara empiris digunakan untuk mengobati disentri, mencret, sariawan, suara parau, dan peradangan gusi. ${ }^{2,3}$ Tanaman gambir secara turun temurun telah digunakan untuk pengobatan tidak hanya di Indonesia, negara lain seperti Bangladesh, India, Pakistan, Taiwan, Jepang, Korea Selatan, Perancis, dan Swiss sebagai negara tujuan ekspor gambir Indonesia pun menggunakan gambir sebagai salah satu bahan baku pembuatan obat namun pengembangan dan penelitian tanaman gambir sebagai obat herbal menuju obat herbal terstandar dan fitofarmaka masih terbatas. ${ }^{4,5}$

Pada umumnya dokter gigi menggunakan pengobatan dengan menggunakan obat sintesis untuk menyembuhkan luka, salah satu obat sintesis yang sering dipakai untuk membantu proses penyembuhan luka adalah chlorhexidine gluconate 0,2\%. Chlorhexidine adalah suatu bisbiguanid yang mempunyai aktivitas antimikrobial dan antiinflamasi. ${ }^{6,8}$ Penggunaan chlorhexidine berulang dan jangka lama dapat menimbulkan efek samping seperti hipersentivitas, dermatitis kontak, fotosensitivitas, dan mengubah warna lidah dan gigi serta bahan tambal resin komposit. ${ }^{6,9}$

Dosis terapi obat yang tepat termasuk salah satu persyaratan terapi rasional meliputi: jenis obat, dosis, bentuk sediaan, dan penggunaan obat yang tepat. Pemilihan dan penetapan dosis harus memperhatikan beberapa faktor, yaitu faktor penderita yang meliputi: umur, bobot badan, jenis kelamin, luas permukaan tubuh, toleransi, habituasi, adiksi dan sensitivitas, serta kondisi penderita faktor obat yang meliputi; sifat kimia dan fisika obat, sifat farmakokinetik, dan jenis obat faktor penyakit yang meliputi; sifat dan jenis penyakit serta kasus penyakit. ${ }^{10}$

Pengobatan alami dengan menggunakan herbal memiliki keuntungan yang jauh lebih banyak dibandingkan pengobatan dengan menggunakan obat sintesis kimia. Penelitan ini dilaksanakan untuk mengetahui pengaruh daun gambir secara topikal terhadap penyembuhan luka pada mukosa palatum dan mengenai dosis efektif ekstrak etanol daun gambir secara topikal dalam penyembuhan luka optimal dibandingkan dengan chlorhexidine gluconate $0,2 \%$ pada mukosa palatum tikus galur wistar membuat peneliti tertarik untuk melakukan penelitian.

\section{BAHAN DAN METODE}

Penelitian ini adalah penelitian eksperimental murni laboratoris yang bersifat analitik yang telah disetujui Komisi Etik Penelitian Kesehatan Fakultas Kedokteran Universitas Padjajaran (No. 030/UN6. C1.3.2/KEPK/PN/2015 No.Reg.: 0214120946). Penelitian dilakukan di Laboratorium Biokimia dan Laboratorium Percobaan Hewan Fakultas Kedokteran Universitas Jenderal Achmad Yani selama bulan November 2014-Januari 2015. Jumlah tikus putih bergalur wistar (Rattus norvegicus) dihitung dengan rumus Federer $(\mathrm{t}-1)(\mathrm{r}-1) \geq 15$, $\mathrm{t}$ merupakan banyak kelompok perlakuan dan $r$ adalah jumlah replikasi atau jumlah sampel, didapat sampel berjumlah 35 ekor. Prosedur penelitian dimulai dari tujuh hari adaptasi hewan uji setelah dilakukan perlukaan menggunakan punch biopsy dengan diameter $4 \mathrm{~mm}$ dengan kedalaman $2 \mathrm{~mm}$. Tikus galur wistar dibagi secara acak menjadi tujuh kelompok yaitu kelompok kontrol negatif (K1), kelompok kontrol positif dengan menggunakan chlorhexidine gluconate $0,2 \%$ (K2), kelompok ekstrak etanol daun gambir dengan dosis 1,75 mg (K3), 3,5 mg (K4), $7 \mathrm{mg}$ (K5), $14 \mathrm{mg}$ (K6) dan $28 \mathrm{mg}$ (K7) dalam bentuk sediaan semipadat. ${ }^{11}$ Chlorhexidine gluconate $0,2 \%$ dan ekstrak etanol daun gambir diaplikasikan pada daerah luka setiap dua kali sehari. Luka diamati pada hari ke-0, 3, 7 dan 14. Pengukuran luas luka dilakukan menggunakan kaliper geser dan penggaris.

Hasil pengamatan ukuran penutupan luka, lama waktu penyembuhan dan dosis efektif menggunakan aplikasi software statistik SPSS versi 22 (Statistical Product and Service Solutions). Data hasil penelitian memiliki distribusi tidak normal sehingga digunakan uji Kruskal-Wallis kemudian dilanjutkan analisis menggunakan uji Mann-Whitney untuk dapat mengetahui kelompok yang mengalami perbedaan. Analisis statistik yang digunakan untuk mengetahui perbedaan hasil luas luka setiap pengukuran luas luka hari ke-0, ke-3, ke-7, dan ke-14 adalah uji Friedman dilanjutkan analisis menggunakan uji Wilcoxon untuk mengetahui kelompok yang memiliki pengaruh paling efektif untuk penyembuhan optimal pada proses penyembuhan luka. ${ }^{12}$

\section{HASIL}

Pada hari ke-0, pengujian statistik dilakukan untuk 
melihat perbedaan pada setiap kelompok yang telah dilakukan perlakuan, didapatkan hasil analisis statistik luas luka dengan menggunakan uji Kruskal-Wallis nilai signifikansi 1,000 lebih besar dari $\alpha=0,05$ yang artinya tidak terdapat perbedaan bermakna dari setiap kelompok perlakuan. ${ }^{12}$

Pada hari ke-3 pengujian statistik dilakukan untuk melihat perbedaan pada setiap kelompok yang telah dilakukan perlakuan. Hasil uji Kruskal-Wallis didapatkan nilai signifikansi 0,003 , lebih kecil dari $\alpha=$ 0,05 artinya terdapat perbedaan bermakna dari setiap kelompok perlakuan, untuk dapat mengetahui kelompok yang mengalami perbedaan perlu dilakukan pengujian dengan uji Mann-Whitney. ${ }^{12}$ Hasil uji Mann-Whitney, menunjukkan perbandingan luas luka pada setiap kelompok perlakuan dan terdapat pula kelompok perlakuan: K1 dan K6, K1 dan K7, K2 dan K6, K2 dan K7, K3 dan K6, K3 dan K7, K4 dan K6, K4 dan K7 memiliki hasil yang berbeda nyata. Pada K1 dan K2, K1 dan K3, K1 dan K4, K1 dan $\mathrm{K} 5$, K2 dan K3, K2 dan K4, K2 dan K5, K3 dan K4, K3 dan K5, K4 dan K5, K5 dan K6, K5 dan $\mathrm{K} 7$, K6 dan $\mathrm{K} 7$ memiliki hasil yang tidak berbeda nyata. ${ }^{11}$

Hasil analisis statistik dengan menggunakan uji Friedman didapatkan nilai signifikansi 0,000 lebih kecil dari $\alpha=0,05$ artinya terdapat perbedaan bermakna dari setiap pengukuran luas luka sejak hari awal perlukaan hingga hari ke-3 pada setiap kelompok perlakuan. Hasil analisis yang diperoleh dapat dikatakan bahwa setiap perlakuan yang diberikan memberikan hasil yang berbeda secara signifikan terhadap pengukuran luas luka untuk dapat mengetahui kelompok yang memiliki pengaruh paling efektif untuk penyembuhan optimal pada proses penyembuhan hari ke-3 perlu dilakukan pengujian dengan uji Wilcoxon, hasilnya menunjukkan pemberian ekstrak etanol daun gambir dosis $28 \mathrm{mg}$ memiliki pengaruh yang lebih efektif terhadap penyembuhan luka mukosa palatum tikus disbandingkan chlorhexidine gluconate $0,2 \%$ pada hari ke-3. ${ }^{12}$

Pada hari ke-7 hasil uji Kruskal-Wallis diperoleh nilai signifikansi 0,001 lebih kecil dari $\alpha=0,05$ artinya terdapat perbedaan bermakna pada setiap kelompok perlakuan, kelompok yang mengalami perbedaan dilakukan pengujian dengan uji Mann-Whitney. Hasil uji Mann-Whitney didapatkan kelompok perlakuan yang berbeda nyata dan tidak berbeda nyata. $\mathrm{K} 1$ dan K6, K1 dan K7, K2 dan K6, K2 dan $\mathrm{K} 7, \mathrm{~K} 3$ dan K6, K3 dan K7, K4 dan K6, K4 dan $\mathrm{K} 7$, K5 dan K6, K5 dan K7 memiliki hasil yang berbeda nyata. K1 dan K2, K1 dan K3, K1 dan K4, $\mathrm{K} 1$ dan K5, K2 dan K3, K2 dan K4, K2 dan K5, K3 dan $\mathrm{K} 4, \mathrm{~K} 3$ dan $\mathrm{K} 5, \mathrm{~K} 4$ dan $\mathrm{K} 5, \mathrm{~K} 6$ dan $\mathrm{K} 7$ memiliki hasil yang tidak berbeda nyata. ${ }^{12}$
Uji Friedman digunakan untuk mengetahui perbedaan hasil luas luka setiap pengukuran hari ke-7. Hasil analisis data didapatkan nilai signifikansi 0,000 , lebih kecil dari $\alpha=0,05$ artinya terdapat perbedaan bermakna dari setiap pengukuran luas luka pada setiap kelompok perlakuan, analisis dilanjutkan dengan uji Wilcoxon yang mendapatkan nilai signifikansi setiap kelompok lebih kecil dari $\alpha=0,05$ artinya terdapat perbedaan bermakna pada setiap kelompok perlakuan tersebut, namun bila dilihat dari hasil signifikansi setiap kelompok, K7 memiliki hasil yang paling kecil dan menjauhi batas 0,05 yang artinya memiliki pengaruh yang lebih besar dari kelompok yang lainnya. Hasil analisis menyimpulkan bahwa ekstrak etanol daun gambir dosis $28 \mathrm{mg}$ merupakan dosis efektif terhadap penyembuhan luka hari ke-7. ${ }^{12}$

Pada hari ke-14 hasil analisis dengan menggunakan uji Kruskal-Wallis diperoleh nilai signifikansi 1,000 lebih besar dari $\alpha=0,05$ artinya tidak terdapat perbedaan bermakna dari setiap kelompok perlakuan. ${ }^{12}$

Hasil analisis statistik dengan menggunakan uji Friedman didapatkan nilai signifikansi 0,000 lebih kecil dari $\alpha=0,05$ artinya terdapat perbedaan bermakna dari setiap pengukuran luas luka hari ke-14 pada setiap kelompok perlakuan. Analisis data dilanjutkan dengan uji Wilcoxon. Hasil analisis menunjukkan nilai signifikansi setiap kelompok yaitu 0,025 , lebih kecil dari $\alpha=0,05$ artinya terdapat perbedaan bermakna pada setiap kelompok perlakuan. ${ }^{12}$

Kelompok ekstrak etanol daun gambir dosis 14 dan $28 \mathrm{mg}$ menunjukkan luka mulai menutup dihari ke-7, sedangkan pada kelompok lainnya luka mulai menutup sampai hari ke-14 didapatkan lama penyembuhan luka selama tujuh hari dibandingkan chlorhexidine gluconate 0,2\% dengan lama penyembuhan luka berlangsung selama empat belas hari.

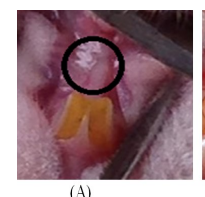

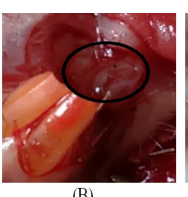

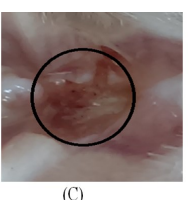

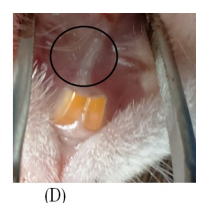

Gambar 1. Gambaran mukosa palatum dosis $28 \mathrm{mg}$. (A) Hari ke-0, sebelum perlakuan. (B) Hari ke-0, sesudah perlakuan. (C) Hari ke-3. (D) Hari ke-7.

\section{PEMBAHASAN}

Pada awal perlukaan mukosa palatum tikus setelah perlakuan terlihat terjadi pendarahan pada sekitar daerah yang telah dilakukan perlukaan dan terlihat 
luas luka $4 \mathrm{~mm}$. Hal ini karena kedalaman punch biopsy sekitar $2 \mathrm{~mm}$ ketika perlakuan mengenai lamina basalis yang terdapat banyaknya pembuluh darah.

Perlakuan pada awal perlukaan luka memasuki fase inflamasi. Fase inflamasi dimulai dari terjadinya luka sampai hari ke-5 yang ditandai dengan gejala radang akut yaitu warna kemerahan karena kapiler melebar (rubor), suhu hangat (calor), rasa nyeri (dolor), dan pembengkakan (tumor). ${ }^{1}$

Pada hari ke-3 fase inflamasi terlihat pada K1, K2, $\mathrm{K} 3$, K4, dan K5 yang ditandai dengan adanya warna kemerahan dan terjadi pembengkakan. Pendarahan sudah tidak tampak pada luka setiap kelompok perlakuan, luas luka sudah tampak mengalami pengecilan, dan pendarahan sudah tidak tampak pada luka setiap kelompok perlakuan. Pada K6 dan K7 pembengkakan dan kemerahan lebih ringan dibandingkan dengan kelompok yang lainnya karena sudah memasuki fase proliferasi dengan memperlihatkan adanya pengerutan tepi luka dan terlihat adanya pertautan jaringan. Hal ini berhubungan dengan efek daun gambir sebagai antiinflamasi, antibakteri, dan antioksidan. ${ }^{13-16}$ Kemampuan antiinflamasinya dipengaruhi oleh kandungan katekin, tanin dan gambiriin yang mampu menurunkan aktivitas enzim lipooksigenase yang menyebabkan tidak terbentuknya leukotrien yang dapat mengaktivasi leukosit yang mengacu terjadinya peradangan dan menghambat enzim siklooksigenase sehingga menyebabkan prostaglandin tidak terbentuk. Apabila terhambatnya oksidasi asam arakhidonat maka oksigen reaktif dan mediator-mediator kimia yang dapat menyebabkan radang tidak terbentuk sehingga proses inflamasi terjadi lebih cepat. ${ }^{13}$ Aktivitas antibakteri daun gambir berhubungan dengan senyawa alkaloid dan saponin yang terkandung di dalamnya. Senyawa alkaloid dapat mengganggu terbentuknya komponen penyusun peptidoglikan pada sel bakteri, sehingga lapisan dinding sel tidak terbentuk secara utuh dan terjadi kematian sel. Saponin yang merupakan glikosida sterol yang bekerja dalam menghambat pertumbuhan bakteri patogen, menghambat fungsi membran sel bakteri dengan merusak permeabilitas membran sel, dan mengakibatkan lisis dinding sel bakteri. ${ }^{15-17}$ Selain itu, senyawa yang dapat berperan sebagai antibakteri lainnya adalah katekin dan asam cathechutannat. Efek antioksidan pada daun gambir dipengaruhi oleh kandungan flavonoid yang mampu menangkal radikal bebas yang akan menghambat proses penyembuhan dan mencegah reaksi berantai radikal bebas. Mekanisme kerja flavonoid termasuk katekin adalah menghambat pembentukan peroksidasi lipid pada tahap inisiasi dengan berperan sebagai scavengers (peredam) terhadap radikal bebas oksigen reaktif maupun radikal hidroksil. ${ }^{18}$

Pada hari ke-3, terlihat bahwa terdapat perbandingan hasil luas luka pada setiap kelompok perlakuan dan terdapat pula kelompok perlakuan yang memiliki hasil yang tidak berbeda nyata, hal ini karena dosis daun gambir yang diberikan semakin tinggi memberikan hasil yang efektif untuk penyembuhan luka dibandingkan dengan tanpa diberi obat dan dengan menggunakan chlorhexidine gluconate $0,2 \% .{ }^{10} \mathrm{~K} 1$ dan $\mathrm{K} 2$, memiliki hasil yang tidak berbeda nyata, hal ini karena chlorhexidine gluconate $0,2 \%$ berperan sebagai antibakteri dan antiinflamasi dalam membantu proses penyembuhan luka dan tidak bisa menghambat gangguan penyembuhan luka dari faktor lainnya seperti radikal bebas. ${ }^{7,8} \mathrm{~K} 1$ dan $\mathrm{K} 3, \mathrm{~K} 1$ dan K4, K1 dan K5, K2 dan K3, K2 dan $\mathrm{K} 4, \mathrm{~K} 2$ dan K5, memiliki hasil yang tidak berbeda nyata, hal ini karena dosis daun gambir yang diberikan terlalu rendah sehingga tidak menimbulkan hasil yang efektif untuk penyembuhan luka dibandingkan dengan tanpa diberi obat dan dengan menggunakan chlorhexidine gluconate $0,2 \% .{ }^{10} \mathrm{~K} 3$ dan K4, K3 dan K5, K4 dan K5, K5 dan K6, K5 dan K7, K6 dan K7 memiliki hasil yang tidak berbeda nyata, hal ini karena dosis daun gambir yang diberikan memiliki efektivitas yang sama terhadap penyembuhan luka. Hasil menunjukkan pada hari ke-3 pemberian ekstrak etanol daun gambir dosis $14 \mathrm{mg}$ dan $28 \mathrm{mg}$ memiliki pengaruh yang lebih efektif terhadap pengecilan luas luka mukosa palatum tikus dibandingkan chlorhexidine gluconate $0,2 \%$.

Pada hari ke-7 luka K1, K2, K3, K4, dan K5 sudah memasuki fase proliferasi dengan ditandai menurunnya tanda-tanda inflamasi seperti pembengkakan dan kemerahan. Pada K6 dan K7 luka sudah memasuki fase remodeling dengan ditandai hilangnya tanda-tanda inflamasi dan sudah terjadi penutupan luka pada beberapa sampel. ${ }^{1}$ Hal ini berhubungan dengan kemampuan daun gambir yang memiliki aktivitas antibakteri dan antioksidan yang berperan pada semua fase proses penyembuhan luka. ${ }^{14-17}$ Efek antibakteri gambir dipengaruhi oleh senyawa flavonoid yang terkandung di dalamnya. ${ }^{15-17}$ Mekanisme kerja flavonoid sebagai antibakteri adalah membentuk senyawa kompleks dengan protein ekstraseluler dan terlarut sehingga dapat merusak membran sel bakteri dan diikuti dengan keluarnya senyawa intraseluler dan dapat bersifat bakteriostatik dan bakterisidal. Faktor yang menyebabkan gambir memiliki antibakteri yaitu karena kandungan katekin, asam cathechutannat, alkaloid dan saponin. ${ }^{15-17}$ Efek antioksidan pada daun gambir dipengaruhi oleh kandungan flavonoid yang mampu menangkal radikal bebas yang akan menghambat proses penyembuhan dan mencegah reaksi berantai 
radikal bebas. Cara kerjanya dengan memberikan donor atom $\mathrm{H}$ kepada radikal peroksil membentuk radikal flavanoid dan akan bereaksi dengan oksigen reaktif (superoksida) sehingga menjadi netral dengan reaksi tersebut, reaksi berantai peroksidasi lipid dapat dihentikan. ${ }^{14}$ Selain itu senyawa turunan flavonoid yang juga bersifat antioksidan dan antioksidan yang terkandung dalam daun gambir adalah quersetin. ${ }^{19}$

Berdasarkan analisis data pada hari ke-7 terlihat bahwa terdapat perbandingan hasil luas luka pada setiap kelompok perlakuan dan terdapat pula kelompok perlakuan yang memiliki hasil yang tidak berbeda nyata. $\mathrm{K} 1$ dan $\mathrm{K} 6, \mathrm{~K} 1$ dan $\mathrm{K} 7, \mathrm{~K} 2$ dan $\mathrm{K} 6$, K2 dan K7, K3 dan K6, K3 dan K7, K4 dan K6, K4 dan K7, K5 dan K6, K5 dan K7 memiliki hasil yang berbeda nyata, hal ini karena dosis daun gambir yang diberikan semakin tinggi memberikan hasil yang efektif untuk penyembuhan luka dibandingkan dengan tanpa diberi obat dan dengan menggunakan chlorhexidine gluconate $0,2 \%{ }^{10} \mathrm{~K} 1$ dan $\mathrm{K} 2$, memiliki hasil yang tidak berbeda nyata, hal ini karena chlorhexidine gluconate $0,2 \%$ berperan sebagai antibakteri dan antiinflamasi dalam membantu proses penyembuhan luka dan tidak bisa menghambat gangguan penyembuhan luka dari faktor lainnya seperti radikal bebas. ${ }^{6-8} \mathrm{~K} 1$ dan $\mathrm{K} 3, \mathrm{~K} 1$ dan $\mathrm{K} 4, \mathrm{~K} 1$ dan $\mathrm{K} 5$, $\mathrm{K} 2$ dan $\mathrm{K} 3, \mathrm{~K} 2$ dan $\mathrm{K} 4, \mathrm{~K} 2$ dan K5, memiliki hasil yang tidak berbeda nyata, hal ini karena dosis daun gambir yang diberikan terlalu rendah sehingga tidak menimbulkan hasil yang efektif untuk penyembuhan luka dibandingkan dengan tanpa diberi obat dan dengan menggunakan chlorhexidine gluconate $0,2 \%{ }^{12} \mathrm{~K} 3$ dan $\mathrm{K} 4, \mathrm{~K} 3$ dan $\mathrm{K} 5, \mathrm{~K} 4$ dan K5, K6 dan K7 memiliki hasil yang tidak berbeda nyata, hal ini karena dosis daun gambir yang diberikan memiliki efektivitas yang sama terhadap penyembuhan luka. Hasil menunjukkan pada hari ke7, pemberian ekstrak etanol daun gambir dosis 14 mg dan $28 \mathrm{mg}$ memiliki pengaruh yang lebih efektif terhadap pengecilan luas luka mukosa palatum tikus dibandingkan chlorhexidine gluconate $0,2 \%$.

Hari ke-14 diameter luka eksisi pada mukosa palatum sudah mengalami penutupan sempurna dibandingkan hari ke-7 pada setiap kelompok. Menurut teori, hari ke-14 penyembuhan luka memasuki fase remodeling yang terdiri atas proses pematangan dan penyerapan kembali jaringan kolagen yang berlebih oleh enzim kolagenase dan matriks metaloproteinase. Semua sampel pada setiap kelompok telah mengalami penutupan luka. Penutupan luka pada hari ke-14 ditandai dengan terbentuknya jaringan baru disekitar luka yang sama dengan jaringan normal. Proses remodeling terjadi lebih dominan pada setiap kelompok perlukaan pada hari ke-14. ${ }^{1}$
Kelompok ekstrak etanol daun gambir dosis 14 dan $28 \mathrm{mg}$ menunjukkan luka mulai menutup dihari ke-7, sedangkan pada kelompok lainnya luka mulai menutup sampai hari ke-14 karena kemampuan yang dimiliki daun gambir sebagai antibakteri, antiinflamasi, dan antioksidan yang membantu proses penyembuhan luka disertai dengan dosis yang efektif membuat proses penyembuhan luka menjadi optimal. ${ }^{13-17}$

Hasil menunjukkan pemberian ekstrak etanol daun gambir dosis $14 \mathrm{mg}$ dan $28 \mathrm{mg}$ memiliki pengaruh yang lebih efektif terhadap lama penyembuhan luka mukosa palatum tikus dengan didapatkan lama penyembuhan luka selama tujuh hari dibandingkan chlorhexidine gluconate $0,2 \%$ dengan lama penyembuhan luka berlangsung selama empat belas hari.

\section{Daftar Pustaka}

1. Hasibuan LY, Hardisiswo S, Bisono. Dalam: Sjamsuhidajat R. Buku ajar ilmu bedah. edisi 3., Jakarta: EGC, 2004: 95-101.

2. Yuniarti T. Ensiklopedia tanaman obat tradisional. Yogyakarta: MedPress, 2008: 112-3.

3. Ismalayani. Efektivitas air rebusan getah gambir (Uncaria gambir) dalam meredakan gingivitis. Wawasan Kependidikan Jurnal Penelitian dan Kajian Ilmiah Kependidikan. 2010; 1: 83-93.

4. Dhalimi Azmi. Permasalahan gambir (Uncaria gambir) di Sumatra Barat dan alternatif pemecahannya. Perspektif. 2006; 5: 46-59.

5. Hernani. Pengembangan biofarmaka sebagai obat herbal untuk kesehatan. Buletin Teknologi Pascapanen Pertanian. 2011; 7: 20-29.

6. Gunawan SG, Setiabudy R, Nafrialdi, Elysabeth. Farmakologi dan terapi. Jakarta: Balai Penerbit FK UI, 2009: 536.

7. Langlais RP, Miller CS, Nield-Gehrig JS. Atlas berwarna lesi mulut yang sering ditemukan. Alih Bahasa. Titi S. edisi 4. Jakarta: EGC, 2014: 194.

8. Montecucco F, Bertolotto M, Ottonello L, Pende A, Dapino P, Quercioli A, et al. Chlorhexidine prevents hypochlorous acid-induced inactivation of $\alpha$ antitrypsin. Clin and Exp Pharmacol Physiol. 2009; 36: $72-7$.

9. Maliki H. Pengaruh obat kumur chlorexidine $0,2 \%$ terhadap perubahan warna pada resin komposit hybrid pasca perawatan bleaching $<$ http://etd. repository.ugm.ac.id/index.php?mod=penelitian_detai $1 \&$ sub=PenelitianDetail\&act=view\&typ $=h t m l \& b u k$ u_id=72346> (6 Juni 2015).

10. Syamsuni H. Farmasetika dasar dan hitungan farmasi. Jakarta: EGC, 2006: 53-4.

11. Peraturan kepala badan pengawas obat dan makanan Republik Indonesia nomor 7 tahun 2014 tentang Pedoman Uji Toksisitas Nonklinik secara In Vivo. 
<file://C:/Users/win7/Downloads/PerKBPOM\%20 Nomor\%207\%20Tahun\%202014\%20tentang\%20 in\%20vivo..pdf $>$ (1 Juni 2015).

12. Dahlan MS. Statistik untuk kedokteran dan kesehatan. edisi 4. Jakarta: Salemba medika, 2009: 96105, 112-8.

13. Sari GP. Uji efek analgetik dan antiinflamasi ekstrak kering air gambir secara in vivo <http://repository.uinjkt.ac.id/dspace/bitstream/123456789/1031/ 1/GITA\%20PERMATA\%20SARI-FKIK.pdf > $(6$ Juni 2015).

14. Anggraini T, Tai A, Yashino T, Itani T. Antioxidative activity and catechin content of four kinds of Uncaria gambir extract from West Sumatra, Indonesia. Afr. J. Biochem. Res. 2011; 5: 33-8.

15. Putri MAH. Uji aktivitas antibakteri +/- katekin dan gambir (Uncaria gambir) terhadap beberapa jenis bakteri gram negatif dan mekanismenya $<$ http://repository.uinjkt.ac.id/dspace/bitstream/1234
$<56789 / 870 / 1 / 9$ Mustikaning\%20Ayu\%20Hapsari\% 20Putri-FKIK.pdf $>$ (6 Juni 2015).

16. Kresnawaty I, Zainuddin. Aktivitas antioksidan dan antibakteri dari derivat metil ekstrak etanol daun gambir (Uncaria gambir). Jurnal Littri. 2009; 14; 145-51.

17. Silvikasari. Aktivitas antibakteri ekstrak kasar flavonoid daun gambir (Uncaria gambir) <http:// repository.ipb.ac.id/bitstream/handle/123456789/47 $533 /$ G11 sil.pdf? sequence $=11 \&$ isAllowed $=y>(6 \mathrm{Ju}-$ ni 2015).

18. Kristanti AN, Aminah NS, Tanjung M, Kurniadi B. Buku ajar fitokimia. Surabaya: Airlangga University Press, 2008.19-22.

19. Gumbira-Sai'd E, Syamsu K, Mardliyati E, Herryandie A, Evalia NA, Rahayu DL, dkk. Agroindustri dan bisnis gambir Indonesia. Bogor: IPB Press, 2009: 16. 